\title{
ATRIBUT-ATRIBUT YANG DINILAI PENTING OLEH WISATAWAN DOMESTIK DAN WISATAWAN CINA DALAM MEMILIH HOTEL DI BALI
}

\author{
Alexandra Carina Saksana ${ }^{1}$, Sienny Thio ${ }^{2}$ \\ ${ }^{1,2}$ Program Manajemen Perhotelan, Program Studi Manajemen, Fakultas Ekonomi, Universitas Kristen Petra \\ Jl. Siwalankerto 121-131, Surabaya, Indonesia \\ Email: alexandracs32@gmail.com ${ }^{1}$, sienny@petra.ac.id ${ }^{2}$
}

\begin{abstract}
Abstrak
Tujuan dari penelitian ini adalah untuk mengidentifikasi atribut-atribut yang dinilai penting oleh wisatawan domestik maupun wisatawan Cina dalam memilih hotel di Bali. Sebanyak 598 kuesioner dikumpulkan dan hanya 565 kuesioner diolah lebih lanjut dengan menggunakan analisa statistik deskriptif. Hasil dari studi ini menunjukkan bahwa atribut kamar seperti kamar dan kamar mandi yang bersih serta ketersediaan amenities merupakan atribut yang dianggap paling penting bagi wisatawan Indonesia dan wisatawan Cina, diikuti dengan atribut keseluruhan (seperti reputasi, lokasi dan harga kamar), atribut layanan dan fasilitas (seperti ketersediaan wifi, staf hotel yang sopan dan ramah) dan atribut makanan dan minuman (seperti kualitas makanan yang baik dan harga makanan yang terjangkau). Bagi wisatawan Cina, lokasi hotel yang aman dan kamar hotel yang bersih menjadi indikator yang dianggap paling penting ketika memilih hotel di Bali. Sedangkan bagi wisatawan Indonesia, kebersihan kamar hotel dan kamar mandi dianggap sebagai aspek yang paling penting.
\end{abstract}

Kata kunci: Bali; hotel attributes; wisatawan domesik; wisatawan Cina.

\begin{abstract}
The purpose of this paper is to identify what attributes are perceived to be important by domestic and Chinese tourists in choosing a hotel in Bali. A total of 598 questionnaires were collected and only 565 questionnaires were processed further using descriptive statistic. The findings revealed that room attributes such as cleanliness of guest room and wash room as well as availability of amenities were perceived to be the most important attribute by Indonesian and Chinese tourists, followed by overall attributes (such as reputation, location and room price), service and facility attributes (such as wifi availability, friendly and polite staff), and food and beverage attributes (such as good quality of food and affordable food price). For Chinese tourists, safe hotel location and clean hotel room were perceived to be the most important indicators when they decide to stay in a hotel in Bali, while for Indonesian tourists, cleanliness of hotel room and wash room were perceived to be the most important aspects.
\end{abstract}

Keywords: Bali, hotel attributes; domestic tourist; Chinese tourist.

\section{PENDAHULUAN}

Pariwisata merupakan salah satu sektor yang memiliki peran strategis dalam mendorong peningkatan penerimaan devisa negara. Pengembangan sektor pariwisata diperlukan untuk mendukung partumbuhan ekonomi dan penguatan ketahanan eksternal ekonomi Indonesia (Bank Indonesia, 2018). Indonesia sendiri memiliki 19 pintu masuk utama dan beberapa pintu masuk minor, dimana tercatat lebih dari 5.6 juta wisatawan asing yang masuk melalui Bandar Udara I Gusti Ngurah Rai, Bali, diikuti oleh Bandar Udara Soekarno Hatta, Jakarta, dengan jumlah 2.7 juta wisatawan asing yang hanya setengah dari jumlah yang masuk melalui Bali (Kementerian Pariwisata, 2018). Hal ini menunjukkan bahwa Bali merupakan destinasi yang paling populer dikunjungi oleh wisatawan asing dimana menurut World's Top 25 Destination 2018 oleh TripAdvisor, Bali menduduki peringkat ke-4 dalam daftar tersebut. Selain wisatawan asing, jumlah wisatawan domestik yang berkunjung ke Bali juga tercatat paling tinggi dibanding jumlah wisatawan domestik yang berkunjung ke destinasi wisata lokal lainnya. Pada tahun 2017, tercatat 8.7 juta wisatawan domestik yang berkunjung ke Bali (Badan Pusat Statistik Provinsi Bali, 2018).

Di sisi lain, Badan Pusat Statistik Provinsi Bali (2018) juga mencatat bahwa wisatawan Cina menempati urutan teratas dari total wisatawan asing yang berkunjung ke Bali. Jumlah wisatawan Cina yang berkunjung ke Bali mengalami peningkatan sebesar $28.6 \%$ dari tahun sebelumnya. Selain itu, Arief 
Yahya, Menteri Pariwisata Arief Yahya juga menyebutkan bahwa selama tahun 2017, wisatawan Cina dinilai sebagai wisatawan dengan 3S (size, sustainability, dan spending) terbesar, dengan total kunjungan sebesar 1,9 juta wisatawan, pertumbuhan sebesar $42,2 \%$, serta menyumbang devisa negara melalui spending sebesar 1,94 juta dollar AS. Oleh karena itu, tidak mengherankan bila target utama dari pasar utama pariwisata Indonesia untuk tahun 2018 adalah Cina (Prodjo, 2018).

Wisatawan domestik dan wisatawan Cina dapat dikatakan menjadi kedua kelompok wisatawan ini merupakan pasar potensial bagi pariwisata Bali. Tsai et al (2011) mengatakan bahwa wisatawan dengan latar belakang kebudayaan yang berbeda akan memiliki kebutuhan dan keinginan yang berbeda. Rhee dan Yang (2015) mengatakan bahwa wisatawan memiliki kebutuhan yang berbeda ketika memilih suatu hotel yang dapat diukur dengan atribut hotel. Atribut hotel, menurut Lewis (1983), merupakan layanan dan fasilitas yang disediakan oleh suatu hotel, dimana atribut-atribut tersebut membantu konsumen untuk memilih suatu hotel daripada hotel-hotel yang lain. Lebih lanjut Jones et al (2000) menyatakan bahwa apabila konsumen mendapatkan apa yang dibutuhkan dan diinginkan, maka konsumen akan mendapatkan kepuasan, yang pada akhirnya akan terjadi kecenderungan untuk melakukan pembelian kembali. Dengan kata lain, ketika hotel dapat memenuhi keinginan dan kebutuhan wisatawan yang datang, maka hotel akan memberikan kepuasan bagi wisatawan yang berkunjung dan diharapkan akan menimbulkan intensi untuk datang kembali. Berdasarkan latar belakang tersebut, diperlukan penelitian lebih lanjut untuk menggali preferensi wisatawan ketika memilih hotel, agar dapat memberikan kepuasan kepada wisatawan dan mendorong intensi wisatawan untuk datang kembali. Selain itu, dengan mengetahui preferensi kedua kelompok wisatawan tersebut, para pengelola hotel dapat mengetahui atribut-atribut yang harus lebih mendapatkan perhatian dan juga menentukan strategi pemasaran yang lebih efektif bagi kedua kelompok wisatawan tersebut.

Sampai saat ini, penulis belum menemukan penelitian yang menganalisa atribut yang dinilai penting oleh wisatawan yang berkunjung ke Bali, secara khusus bagi wisatawan domestik dan wisatawan Cina. Padahal kedua kelompok wisatawan tersebut memiliki peran yang besar bagi peningkatan pariwisata di Bali. Oleh sebab itu, penulis tertarik untuk mengetahui lebih dalam mengenai atributatribut yang dinilai penting bagi wisatawan domestik dan wisatawan Cina serta kontribusi dari atribut- atribut tersebut dalam mendorong kedua kelompok wisatawan tersebut dalam memilih hotel di Bali.

\section{TINJAUAN PUSTAKA}

\section{Atribut Hotel}

Setiap hotel menawarkan berbagai macam layanan dan fasilitas yang biasanya berbeda antara satu dengan lainnya. Menurut Lewis (1983), layanan dan fasilitas yang ditawarkan oleh sebuah hotel disebut sebagai atribut hotel, dimana atribut-atribut tersebut membantu konsumen untuk memilih suatu produk daripada produk yang lain. Sebuah hotel bisa memiliki banyak atribut seperti yang dijabarkan oleh beberapa peneliti terdahulu yang dapat dilihat di Tabel 1.

Melalui penelitian-penelitian terdahulu diatas, penulis mengadopsi atribut-atribut hotel dari penelitian Tsai et al (2011), karena dinilai sudah bisa mencakup atribut-atribut yang disebutkan oleh penelitian-penelitian lainnya. Atribut-atribut tersebut adalah (1) atribut keseluruhan, dimana atribut ini mencakup atribut nilai, atribut lokasi, atribut keamanan, serta atribut image; (2) atribut layanan dan fasilitas; (3) atribut kamar; dan (4) atribut makanan dan minuman (food and beverage). Atribut-atribut di atas juga didukung dengan indikator-indikator yang diadopsi dari gabungan penelitian-penelitian Dolnicar dan Otter (2003), Rhee dan Yang (2015), Tsai et al (2011), serta Zhou et al (2014).

\section{Definisi Wisatawan}

Wisatawan, menurut Suwantoro (2004), merupakan seseorang atau kelompok orang yang melakukan suatu perjalanan, dan tinggal lebih dari 24 jam. Apabila durasi kunjungan kurang dari 24 jam, maka pengunjung disebut pelancong (execursionist). Pengertian yang serupa juga disampaikan oleh Soekadijo (1996), dimana wisatawan merupakan pengunjung yang datang sekurang-kurangnya 24 jam, dan yang datang berdasarkan motivasi yaitu untuk bersenang-senang, berlibur, untuk kesehatan, studi, keperluan agama, olahraga, berbisnis, mengunjungi keluarga, perutusan, atau menghadiri pertemuan. Sedangkan pengunjung yang hanya tinggal tanpa bermalam disebut eksekursionis. Berdasarkan asalnya, wisatawan dibagi menjadi wisatawan domestik dan wisatawan mancanegara.

\section{Wisatawan Domestik}

Wisatawan domestik adalah wisatawan yang melakukan perjalanan wisata di dalam negerinya 
Tabel 1. Ringkasan Atribut-atribut Hotel

\begin{tabular}{|c|c|}
\hline Penulis & Atribut Hotel \\
\hline 1. Dolnicar dan Otter (2003) & $\begin{array}{l}\text { a. Atribut image (seperti: ketidakasingan terhadap merek, penilaian ulasan, dan reputasi) } \\
\text { b. Atribut nilai (seperti: harga kamar, value for money, potongan harga) } \\
\text { c. Atribut umum hotel (seperti: ukuran hotel, kebersihan hotel, kolam renang dan fasilitas } \\
\text { kebugaran) } \\
\text { d. Atribut kamar (seperti: ukuran kamar, kebersihan dan kenyamanan kamar, kamar kedap } \\
\text { suara, amenities kamar mandi) } \\
\text { e. Atribut layanan (seperti: kecepatan check-in dan check-out, layanan laundry dan wake- } \\
\text { up call, room service } 24 \text { jam, keramahan staf) } \\
\text { f. Atribut pemasaran (seperti: word-of-mouth, rekomendasi dari agen perjalanan) } \\
\text { g. Atribut makanan dan minuman (seperti: kualitas makanan dan minuman) } \\
\text { h. Atribut keamanan (seperti: keamanan hotel dan kamar, keamanan kawasan hotel) } \\
\text { i. Atribut lokasi (seperti: mudah untuk ke bandara dan pusat kota, mudah untuk mencari } \\
\text { j. Atribut lain-lain (seperti: hadiah dan newsletter hotel) }\end{array}$ \\
\hline 2. Irawan (2014) & $\begin{array}{l}\text { a. Produk (seperti: merek, kebersihan, kolam renang, pelayanan yang baik, makan pagi, } \\
\text { akses internet gratis) } \\
\text { b. Harga (seperti: tarif kamar, potongan harga) } \\
\text { c. Promosi (seperti: program member, promosi iklan) } \\
\text { d. Referensi (seperti: referensi dari teman dan keluarga, ulasan online) }\end{array}$ \\
\hline 3. Rhee dan Yang (2015) & $\begin{array}{l}\text { a. Atribut nilai (seperti: harga kamar, kamar termasuk makan pagi) } \\
\text { b. Atribut layanan (seperti: keramahan dan profesionalitas staf, room service } 24 \text { jam) } \\
\text { c. Atribut kamar (seperti: ukuran, kebersihan, dan kenyaman kamar) } \\
\text { d. Atribut kualitas tidur (seperti: kenyamanan tempat tidur, kamar kedap suara) } \\
\text { e. Atribut lokasi (seperti: mudah untuk ke bandara dan stasiun transportasi umum) } \\
\text { f. Atribut kebersihan (seperti: kebersihan lobi, lift, dan koridor hotel) }\end{array}$ \\
\hline 4. Tsai et al (2011) & $\begin{array}{l}\text { a. Atribut keseluruhan (seperti: value for money, kemudahan menuju tempat wisata, } \\
\text { keamanan, harga kamar, suasana, reputasi) } \\
\text { s. Atribut layanan dan fasilitas (seperti: efisiensi check-in dan check-out, room service } 24 \\
\text { jam, transportasi dari dan ke bandara) } \\
\text {.. Atribut kamar (seperti: kebersihan, ukuran, kenyamanan tempat tidur, kamar kedap } \\
\text { suara) } \\
\text { d. Atribut makanan and minuman (seperti: pilihan restoran yang beragam, kualitas } \\
\text { makanan di restoran dan room service) }\end{array}$ \\
\hline 5. Zhou et al (2014) & $\begin{array}{l}\text { a. Atribut kamar (seperti: amenities kamar dan kamar mandi, ukuran kamar) } \\
\text { b. Atribut hotel (seperti: akses wifi, fasilitas public, usia bangunan) } \\
\text { c. Atribut makanan (seperti: variasi dan kualitas makanan) } \\
\text { d. Atribut nilai (seperti: harga kamar dan harga makanan) } \\
\text { e. Atribut lokasi (seperti: dekat dari bandara dan pusat kota) } \\
\text { f. Atribut karyawan (seperti: kemampuan Bahasa, keramahan staf, dan efisiensi staf) }\end{array}$ \\
\hline
\end{tabular}

sendiri. Wisatawan domestik juga dapat diartikan sebagai seorang warga negara suatu negara yang melakukan perjalanan wisata dalam batas wilayah negaranya sendiri tanpa melewati perbatasan Negaranya (Nasrul, 2010). Oleh karena itu, yang disebut wisatawan domestik di Indonesia adalah orang Indonesia sendiri atau disebut juga dengan wisatawan nusantara/dalam negeri. Wisatawan domestik sangat berpotensi untuk menjadi pasar yang menjanjikan khususnya bagi industri perhotelan mengingat besarnya penduduk Indonesia. Peningkatan penduduk yang berpergian di dalam negeri diyakini masih sangat besar baik untuk berlibur maupun untuk urusan pekerjaan (Yustiana, 2018).
Menurut Sejati (2019), wisatawan domestik atau Indonesia mempunyai karakter yang relatif mudah untuk dimengerti walaupun terkadang kurang displin, lebih menyukai fasilitas yang tidak mahal, fleksibel, dan cenderung untuk berbelanja bila melakukan perjalanan wisata. Wisatawan milenial Indonesia diprediksi berkontribusi sekitar $70 \%$ dari total kunjungan wisatawan dalam negeri setiap tahunnya dan berpotensi terhadap peningkatan kunjungan wisata domestic (Petriella, 2018). Hal ini bisa terealisasi bila pemerintah Indonesia benar-benar serius untuk menggarap pasar milenial ini ditengah gencarnya promosi yang dilakukan oleh negara-negara lain seperti Korea Selatan dan Jepang. Kelompok milenial ini, lebih 
lanjut dikatakan oleh Petriella (2018) cenderung untuk tidak mengeluarkan banyak uang dalam melakukan perjalanan wisata sehingga kaum milenial ini lebih memilih untuk menginap di hotel yang murah atau hotel tidak berbintang.

\section{Wisatawan Cina}

Menurut Sihite (2000), wisatawan mancanegara adalah warga negara suatu negara yang mengadakan perjalanan wisata keluar lingkungan dari negaranya (memasuki negara lain). Lebih jelas dikatakan oleh Musanef (1996), wisatawan mancanegara adalah orang-orang yang mengadakan perjalanan dalam jangka minimal 24 jam dan maksimal tiga bulan ke negara lain atau negara yang bukan tempat mereka biasa tinggal, serta tujuannya bukan untuk bekerja tetap atau tidak menetap disana. Jadi, wisatawan Cina adalah orang asing yang merupakan warga negara Cina dan masuk ke Indonesia.

Menurut Li et al (2010), wisatawan Cina memiliki beberapa standar yang serupa dengan wisatawan lain dalam memilih hotel, yaitu atribut kebersihan, keamanan, dan lokasi sebagai atribut-atribut yang dinilai penting. Selain itu, sebagian besar hotel di Cina menyediakan amenities standar dalam kamar, karena wisatawan Cina terbiasa untuk tidak membawa perlengkapan mandi saat berpergian. Oleh sebab itu, ketersediaan amenities merupakan salah satu hal yang penting bagi wisatawan Cina. Lebih lanjut, Yao (2006) menyatakan bahwa wisatawan Cina juga dinilai sangat sensitif dengan harga sebagai dampak dari konfusianisme di Cina. Wisatawan Cina menganggap berhemat dalam memilih suatu barang merupakan sebuah kebaikan. Oleh karena itu wisatawan Cina cenderung memilih barang yang lebih murah dibanding kualitas yang lebih baik. Meskipun begitu, dalam penelitian ini juga dikatakan bahwa wisatawan Cina memiliki kecenderungan untuk memiliki pengeluaran yang besar saat berwisata, namun digunakan untuk hal-hal selain akomodasi, seperti berbelanja.

\section{METODE PENELITIAN}

Penelitian ini merupakan penelitian kuantitatif deskriptif dimana metode pemilihan sampelnya menggunakan Non-Probability Sampling dengan Purposive Sampling. Adapun sampel dalam penelitian adalah wisatawan domestik dan wisatawan Cina yang sudah pernah berkunjung ke Bali dalam 5 tahun terakhir. Bali dinilai sebagai destinasi wisata yang popular, baik bagi wisatawan domestik maupun wisatawan asing dimana kunjungan wisatawan manca- negara didominasi oleh wisatawan dari Cina. Oleh karena itu, dua kelompok wisatawan ini yang dipilih untuk mengetahui atribut-atribut yang dianggap penting dalam pemilihan hotel di Bali.

Penyebaran kuesioner dilakukan selama dua bulan dengan kurun waktu November-Desember 2018. Kuesioner untuk wisatawan domestik disebarkan secara online dengan menggunakan Google Form, dimana kuisioner ditulis dalam Bahasa Indonesia, dan disebarkan kepada teman, relasi, dan keluarga dari Penulis, selain itu Penulis juga menyebarkan ke responden yang mudah untuk ditemui untuk mengisi kuesioner.

Sedangkan kuesioner untuk wisatawan Cina ditulis dalam Bahasa Mandarin (Putonghua), dan disebarkan secara online ke responden di Cina dengan menggunakan website bernama Wen Juan Xing, yang merupakan website serupa dengan Google Form yang dapat diakses oleh responden di Cina. Adapun penyebarannya, Penulis mendapatkan bantuan dari temanteman Penulis yang berdomisili di Cina.

Total 294 kuesioner diperoleh dari responden wisatawan domestik dan 304 kuesioner dari responden wisatawan Cina. Setelah melakukan proses pembersihan data, terdapat 278 responden wisatawan domestik dan 287 responden wisatawan Cina yang siap untuk dianalisa lebih lanjut. Analisa statistik deskriptif dengan menggunakan mean dan standar deviasi digunakan dalam penelitian ini untuk mengetahui atribut-atribut apa saja yang dianggap penting oleh wisatawan domestik dan wisatawan Cina.

\section{HASIL PENELITIAN DAN PEMBAHASAN}

\section{Karakteristik Responden}

Berdasarkan table 2 dapat dilihat jumlah yang relative sama antara responden domestik dan Cina yang berjenis kelamin laki-laki maupun perempuan dengan mayoritas berusia 17-23 tahun $(61,51 \%)$ untuk responden domestik dan 24-37 tahun (45\%) untuk responden Cina. Mayoritas responden dari dua kelompok wisatawan tersebut memiliki tingkat pendidikan sarjana atau S1 dengan penghasilan rata-rata per bulan dibawah Rp 5 juta untuk responden domestic $(51 \%)$ dan antara $¥ 4800-7200$ untuk responden Cina $(36 \%)$. Sedangkan untuk frekuensi kunjungan ke Bali dalam 5 tahun terakhir, sebagian besar responden domestik berkunjung sebanyak 2-3 kali $(46 \%)$ sedangkan responden Cina hanya 1 kali saja (71\%). Responden Indonesia lebih sering berkunjung ke Bali bersama dengan keluarga dan menginap di hotel bintang 3, sedangkan Responden Cina lebih cenderung untuk mengajak teman ketika ke Bali dan menginap di hotel budget. 
Tabel 2. Profil Responden Wisatawan Domestik dan Wisatawan Cina

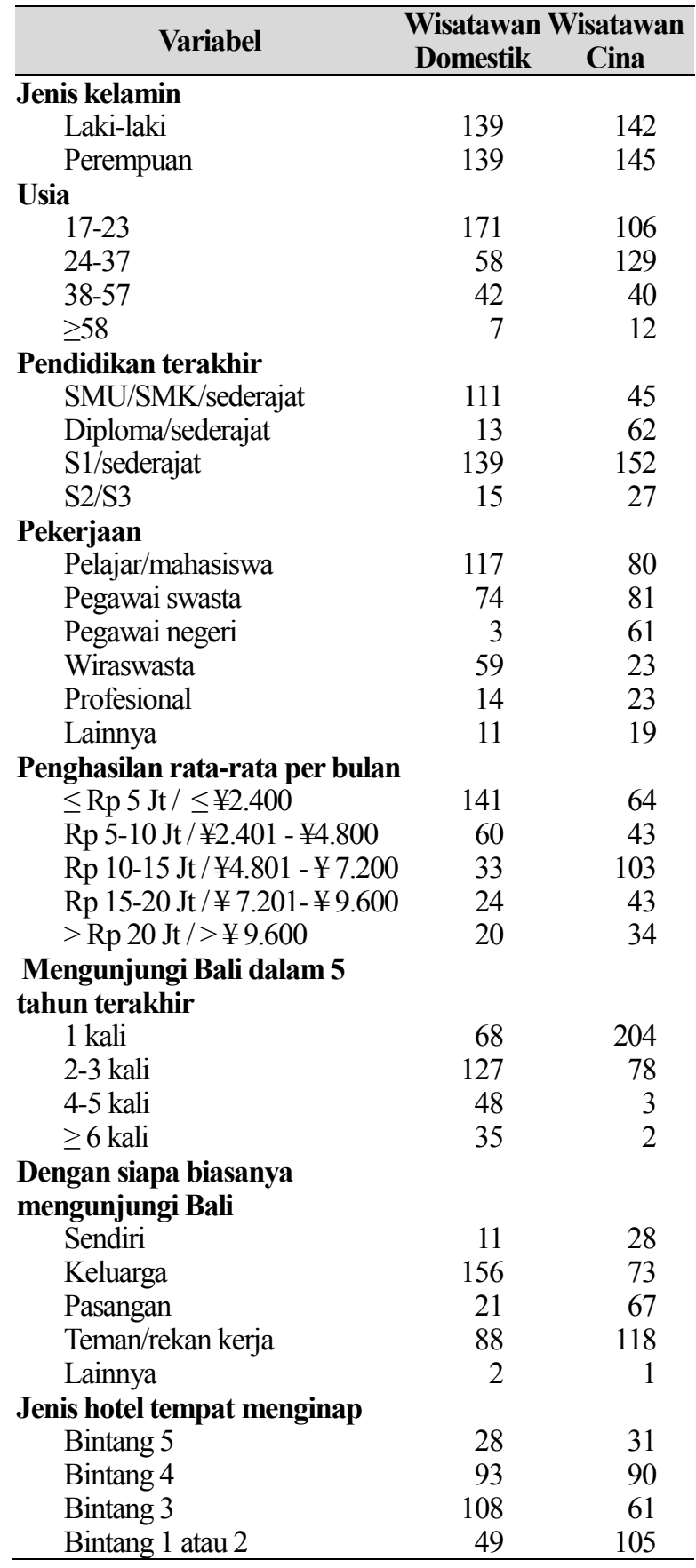

\section{Analisa Statistik Deskriptif untuk Wisatawan Domestik}

Dalam studi ini, perhitungan nilai mean untuk setiap pernyataan di kuesioner digunakan untuk mengetahui atribut-atribut hotel yang dianggap penting oleh responden Indonesia dan Cina ketika berkunjung ke Bali. Penelitian ini mengukur empat atribut hotel yaitu atribut keseluruhan, layanan dan fasilitas, kamar, dan makanan dan minuman dengan menggunakan lima skala Likert dari sangat tidak penting sampai sangat penting. Adapun hasil mean dari responden domestik dan responden China dapat dilihat di Table 3 dan Tabel 4.

Dari Tabel 3 dan Tabel 4 di atas dapat dilihat bahwa baik wisatawan domestik dan wisatawan Cina memiliki urutan kepentingan yang sama dalam memilih untuk menginap di hotel yang ada di Bali, yaitu atribut keseluruhan di posisi pertama, lalu diikuti dengan atribut kamar, atribut layanan dan fasilitas, lalu terakhir atribut makanan dan minuman. Tsai et al (2011) mengatakan bahwa wisatawan dengan latar belakang kebudayaan yang berbeda akan memiliki kebutuhan dan keinginan yang berbeda. Melalui hasil dari mean dan standar deviasi indikator masingmasing atribut untuk kedua kelompok responden, dapat dilihat bahwa wisatawan domestik dan wisatawan Cina memiliki atribut-atribut penting yang berbeda, meskipun tidak berbeda terlalu banyak.

Dapat dilihat pula bahwa wisatawan domestik dalam hal atribut keseluruhan, atribut kamar, dan atribut makanan dan minuman memiliki nilai mean yang lebih besar daripada wisatawan Cina, hal ini menunjukkan bahwa wisatawan domestik memiliki kriteria yang lebih tinggi dalam atribut-atribut tersebut dibanding wisatawan Cina. Sedangkan untuk atribut layanan dan fasilitas, wisatawan Cina memiliki kriteria yang lebih tinggi dibanding wisatawan domestik.

Menurut responden wisatawan domestik, indikator paling penting dari atribut keseluruhan adalah lokasi hotel aman. Hasil ini mendukung pendapat Reisinger dan Turner (1997) yang mengatakan bahwa orang Indonesia cenderung memilih tempat yang aman, nyaman, bersih, dan memiliki layanan yang baik.

Menurut wisatawan Cina, lokasi hotel aman, lalu reputasi hotel baik, dan harga kamar yang sesuai merupakan tiga indikator yang dianggap paling penting dari atribut keseluruhan. Indikator lokasi hotel aman sesuai dengan pendapat Qu dan Li (1997) yang mengatakan bahwa wisatawan Cina cenderung memilih hotel dengan lokasi yang aman. Namun Qu dan Li juga mengatakan bahwa atribut harga merupakan atribut yang dinilai tidak penting bagi wisatawan Cina. Padahal, menurut penelitian ini, harga kamar merupakan sesuatu yang dinilai penting oleh wisatawan Cina. Hasil ini mendukung pendapat dari penelitian lain oleh Yao (2006), yang mengatakan wisatawan Cina dinilai sangat sensitif dengan harga. Sedangkan untuk reputasi hotel, hasil yang diperoleh pada penelitian ini mendukung pendapat Gilbert dan Tsao (2000), yang mengatakan bahwa wisatawan Cina akan lebih cenderung memilih hotel berdasarkan image hotel. Hal ini dikarenakan wisatawan Cina dinilai sangat sensitif terhadap konsep "wajah". 
Tabel 3. Hasil Mean dan Standar Deviasi Responden Wisatawan Domestik

\begin{tabular}{|c|c|c|c|}
\hline Atribut Hotel & Indikator & Mean & SD \\
\hline \multirow[t]{13}{*}{ Atribut Keseluruhan } & Lokasi hotel aman & 4.88 & 0.356 \\
\hline & Harga kamar yang sesuai & 4.73 & 0.525 \\
\hline & Reputasi hotel baik & 4.59 & 0.640 \\
\hline & Ulasan positif dari internet & 4.39 & 0.779 \\
\hline & Lokasi hotel mudah untuk mencari tempat makan & 4.19 & 1.138 \\
\hline & Kemudahan dari hotel menuju tempat wisata & 4.00 & 1.148 \\
\hline & Harga kamar termasuk makan pagi & 3.96 & 1.125 \\
\hline & Hotel memiliki lokasi dengan pemandangan yang indah & 3.80 & 1.163 \\
\hline & Lokasi hotel merupakan lokasi yang tenang & 3.62 & 1.332 \\
\hline & & 3.49 & 1.245 \\
\hline & Kemudahan dari hotel menuju bandara & 2.77 & 1.210 \\
\hline & Hotel memiliki program membership & 4.04 & 0.969 \\
\hline & Mean atribut keseluruhan & & \\
\hline \multirow{11}{*}{$\begin{array}{l}\text { Atribut Layanan dan } \\
\text { fasilitas }\end{array}$} & Hotel menyediakan wifi gratis & 4.64 & 0.684 \\
\hline & Staf hotel sopan & 4.60 & 0.585 \\
\hline & Staf hotel ramah & 4.59 & 0.616 \\
\hline & Staf hotel memberikan layanan dengan cepat & 4.48 & 0.791 \\
\hline & Hotel memiliki kolam renang & 2.59 & 1.103 \\
\hline & Hotel menyediakan layanan room service 24 jam & 2.53 & 0.993 \\
\hline & Hotel memiliki ruangan business centre & 2.47 & 1.233 \\
\hline & Hotel memiliki fasilitas antar jemput dari dan ke bandara & 2.10 & 0.719 \\
\hline & Hotel memiliki fasilitas kebugaran & 2.09 & 1.025 \\
\hline & Hotel memiliki taman bermain anak-anak & 1.96 & 0.987 \\
\hline & Mean atribut layanan dan fasilitas & 3.21 & 0.874 \\
\hline \multirow[t]{7}{*}{ Atribut kamar } & Kamar mandi yang bersih & 4.92 & 0.265 \\
\hline & Kamar hotel yang bersih & 4.92 & 0.283 \\
\hline & Ukuran kamar mandi yang memadai & 4.43 & 0.664 \\
\hline & Ukuran tempat tidur yang luas & 4.38 & 0.760 \\
\hline & Ukuran kamar yang luas & 4.21 & 0.862 \\
\hline & $\begin{array}{l}\text { Kamar menyediakan amenities, seperti sabun, shampoo, sikat gigi, shower } \\
\text { cap) }\end{array}$ & 2.10 & 0.881 \\
\hline & Mean atribut kamar & 4.16 & 0.619 \\
\hline \multirow{12}{*}{$\begin{array}{l}\text { Atribut makanan dan } \\
\text { minuman }\end{array}$} & Harga makanan di hotel terjangkau & 2.78 & 1.483 \\
\hline & Harga minuman di hotel terjangkau & 2.77 & 1.517 \\
\hline & Restoran yang ada di dalam hotel bersih & 2.59 & 1.191 \\
\hline & Hotel memiliki banyak pilihan restoran & 2.22 & 0.906 \\
\hline & Kualitas makanan di restoran hotel baik & 2.19 & 1.130 \\
\hline & Bar/lounge yang ada di dalam hotel bersih & 2.19 & 1.205 \\
\hline & Kualitas minuman di restoran hotel baik & 1.97 & 1.179 \\
\hline & Kualitas minuman di bar/lounge hotel baik & 1.97 & 1.320 \\
\hline & Kualitas makanan room service hotel baik & 1.86 & 1.284 \\
\hline & Kualitas minuman room service hotel baik & 1.83 & 1.255 \\
\hline & Kualitas makanan di bar/lounge hotel baik & 1.73 & 1.134 \\
\hline & Mean atribut makanan dan minuman & 2.19 & 1.237 \\
\hline
\end{tabular}

Untuk atribut layanan dan fasilitas, indikator yang dirasakan paling penting untuk wisatawan Indonesia dan Cina adalah ketersediaan wi-fi secara gratis, staf hotel yang ramah dan sopan. Kebutuhan akan internet telah menjadi salah satu kebutuhan yang tidak bisa diabaikan saat ini. Hal ini juga dikarenakan lebih dari $80 \%$ responden dalam penelitian ini adalah kaum muda dengan usia 17 sampai 37 tahun sehingga keberadaan akan wifi ini dinilai penting ketika memilih sebuah hotel. Selain itu, pelayanan yang sopan dan ramah dari staf hotel juga dianggap penting oleh dua grup wisatawan ini mengingat hotel merupakan industri jasa dimana ada kebutuhan dari tamu hotel untuk diperlakukan dengan pelayanan yang baik dan memuaskan.

Indikator yang dianggap paling penting untuk atribut kamar adalah kamar hotel yang bersih, kamar mandi yang bersih, dan kamar menyediakan amenities. Hasil pada penelitian ini yang menunjukkan pentingnya ketersediaan amenities juga sesuai dengan 
Tabel 4. Hasil Mean dan Standar Deviasi Responden Wisatawan Cina

\begin{tabular}{|c|c|c|c|}
\hline Atribut Hotel & Indikator & Mean & SD \\
\hline \multicolumn{2}{|c|}{ Atribut Keseluruhan Lokasi hotel aman } & 4.80 & 0.543 \\
\hline & Reputasi hotel baik & 4.48 & 0.801 \\
\hline & Harga kamar yang sesuai & 4.35 & 0.915 \\
\hline & Ulasan positif dari internet & 4.31 & 1.057 \\
\hline & Kemudahan dari hotel menuju tempat wisata & 3.92 & 1.014 \\
\hline & Lokasi hotel mudah untuk mencari tempat makan & 3.77 & 1.129 \\
\hline & Hotel memiliki lokasi dengan pemandangan yang indah & 3.44 & 1.230 \\
\hline & Kemudahan dari hotel menuju bandara & 3.28 & 1.096 \\
\hline & Harga kamar termasuk makan pagi & 3.17 & 1.289 \\
\hline & Lokasi hotel merupakan lokasi yang tenang & 2.92 & 1.434 \\
\hline & Hotel memiliki program membership & 2.20 & 1.190 \\
\hline & Mean atribut keseluruhan & 3.69 & 1.063 \\
\hline \multirow{11}{*}{$\begin{array}{l}\text { Atribut Layanan } \\
\text { dan fasilitas }\end{array}$} & Hotel menyediakan wifi gratis & 4.67 & 0.572 \\
\hline & Staf hotel ramah & 3.81 & 1.045 \\
\hline & Staf hotel sopan & 3.68 & 1.110 \\
\hline & Hotel memiliki fasilitas antar jemput dari dan ke bandara & 3.67 & 0.996 \\
\hline & Staf hotel memberikan layanan dengan cepat & 3.60 & 1.216 \\
\hline & Hotel menyediakan layanan room service 24 jam & 3.09 & 1.404 \\
\hline & Hotel memiliki kolam renang & 2.85 & 1.333 \\
\hline & Hotel memiliki fasilitas kebugaran & 2.66 & 1.487 \\
\hline & Hotel memiliki ruangan business centre & 2.53 & 1.348 \\
\hline & Hotel memiliki taman bermain anak-anak & 2.40 & 1.423 \\
\hline & Mean atribut layanan dan fasilitas & 3.30 & 1.193 \\
\hline \multirow[t]{7}{*}{ Atribut kamar } & Kamar hotel yang bersih & 4.72 & 0.637 \\
\hline & Kamar mandi yang bersih & 4.27 & 1.005 \\
\hline & $\begin{array}{l}\text { Kamar menyediakan amenities, seperti sabun, shampoo, sikat gigi, shower } \\
\text { cap) }\end{array}$ & 3.78 & 1.066 \\
\hline & Ukuran kamar yang luas & 3.57 & 1.071 \\
\hline & Ukuran kamar mandi yang memadai & 3.40 & 1.166 \\
\hline & Ukuran tempat tidur yang luas & 3.25 & 1.249 \\
\hline & Mean atribut kamar & 3.83 & 1.032 \\
\hline Atribut makanan & Kualitas makanan di restoran hotel baik & 2.25 & 1.223 \\
\hline \multirow[t]{11}{*}{ dan minuman } & Kualitas minuman di bar/lounge hotel baik & 2.01 & 0.963 \\
\hline & Hotel memiliki banyak pilihan restoran & 1.94 & 1.076 \\
\hline & Bar/lounge yang ada di dalam hotel bersih & 1.92 & 0.999 \\
\hline & Restoran yang ada di dalam hotel bersih & 1.86 & 0.945 \\
\hline & Harga makanan di hotel terjangkau & 1.74 & 1.012 \\
\hline & Harga minuman di hotel terjangkau & 1.74 & 1.134 \\
\hline & Kualitas makanan di bar/lounge hotel baik & 1.58 & 0.797 \\
\hline & Kualitas minuman di restoran hotel baik & 1.55 & 0.782 \\
\hline & Kualitas makanan room service hotel baik & 1.37 & 0.722 \\
\hline & Kualitas minuman room service hotel baik & 1.19 & 0.501 \\
\hline & Mean atribut makanan dan minuman & 1.74 & $\mathbf{0 . 9 2 3}$ \\
\hline
\end{tabular}

penelitian oleh $\mathrm{Li}$ et al (2010), yang mengatakan bahwa wisatawan Cina akan cenderung untuk memilih hotel yang menyediakan amenities standar dalam kamar, karena wisatawan Cina terbiasa untuk tidak membawa perlengkapan mandi saat berpergian.

Bagi responden domestik, indikator-indikator yang dianggap penting dari atribut makanan dan minuman adalah harga makanan dan minuman yang terjangkau, sedangkan untuk responden Cina, kualitas makanan dan minuman dirasakan lebih penting daripada harga. Hal ini menunjukkan bahwa wisatawan Indonesia lebih sensitif terhadap harga dibandingkan wisatawan Cina.
Sedangkan kualitas makanan dan minuman yang ada di barllounge hotel dan room service menjadi indikator yang dianggap kurang penting dalam atribut makanan dan minuman. Hal ini dikarenakan responden wisatawan domestik pada penelitian ini sebagian besar mengunjungi Bali bersama keluarga, sehingga cenderung untuk tidak mengunjungi bar/lounge hotel. Selain itu, responden wisatawan domestik pada penelitian ini sebagian besar merupakan pelajar atau mahasiswa, sehingga harga makanan dan minuman yang ada pada room service dinilai memiliki harga yang dianggap terlalu tinggi khususnya bagi para pelajar atau mahasiswa. 
Namun secara keseluruhan, hasil tingkat kepentingan atribut yang dinilai penting oleh wisatawan Cina dalam memilih hotel pada penelitian ini tidak mendukung penelitian sebelumnya yang dilakukan oleh Tsai et al (2011), dimana pada penelitian tersebut, untuk kategori atribut keseluruhan, wisatawan Cina menilai harga kamar sebagai indikator paling penting. Untuk kategori atribut layanan dan fasilitas, wisatawan Cina menilai indikator staf hotel ramah merupakan indikator yang paling penting dan untuk atribut kamar, indikator kamar hotel bersih dinilai paling penting. Sedangkan untuk atribut makanan dan minuman, indikator hotel memiliki banyak pilihan restoran di dalam hotel dinilai sebagai atribut yang paling penting. Hal ini menunjukkan bahwa destinasi yang berbeda membuat perbedaan pada atribut-atribut yang dianggap penting dalam memilih hotel di Bali. Dalam penelitian Tsai et al (2011) tersebut, penelitian dilakukan pada wisatawan Cina yang mengunjungi Hong Kong. Karakteristik destinasi yang berbeda antara Hong Kong dan Bali membuat wisatawan Cina mempunyai preferensi yang berbeda dalam menentukan pilihan hotel. Harga kamar di Hong Kong yang jauh lebih mahal dari harga kamar di Bali, membuat wisatawan Cina mempertimbangkan faktor harga menjadi sangat penting ketika memilih hotel di Hong Kong.

\section{KESIMPULAN DAN SARAN}

Wisatawan domestik maupun wisatawan China mempunyai urutan yang sama dalam menilai atributatribut yang dianggap penting dalam dalam memilih sebuah hotel ketika menginap di Bali. Atribut kamar (seperti kamar dan kamar mandi yang bersih serta ketersediaan amenities) merupakan atribut yang dianggap paling penting yang diikuti dengan atribut keseluruhan (seperti reputasi, lokasi dan harga kamar), atribut layanan dan fasilitas (seperti ketersediaan wifi, staf hotel yang sopan dan ramah) dan yang terakhir adalah atribut makanan dan minuman (seperti kualitas makanan yang baik dan harga makanan yang terjangkau).

Bagi wisatawan Cina, lokasi hotel yang aman dan kamar hotel yang bersih menjadi indikator yang dianggap paling penting ketika memilih hotel di Bali. Sedangkan bagi wisatawan Indonesia, kebersihan kamar hotel dan kamar mandi dianggap sebagai aspek yang paling penting. Kualitas makanan dan minuman di tersedia di room service menjadi faktor yang dianggap paling tidak penting dalam menentukan tempat menginap di Bali. Hal ini mengingat responden yang sebagian besar adalah para pelajar dan mahasiswa yang memiliki kecenderungan untuk menikmati makanan di luar hotel.
Dengan mengetahui atribut-atribut hotel yang dianggap penting khususnya kaum milenial ini, diharapkan dapat memberikan masukan bagi pelaku industri perhotelan khususnya di Bali untuk dapat memberikan pelayanan atau fasilitas yang menjadi prioritas utama bagi wiasatawan milenial domestik maupun Cina yang merupakan dua pasar potensial bagi bisnis penginapan di Bali. Sedangkan keterbatasan dalam penelitian ini adalah hasil penelitian ini tidak menggambarkan preferensi wisatawan secara umum tetapi hanya memberikan gambaran bagi wisatawan Indonesia dan wisatawan China usia muda saja. Hal ini dikarenakan sekitar $80 \%$ dari total responden mempunyai rentang usia antara 17 tahun sampai dengan 37 tahun. Penelitian selanjutnya diharapkan dapat melakukan wawancara untuk mendapatkan jawaban yang lebih mendalam beserta alasan-alasan mengenai atribut-atribut yang dinilai penting dalam memilih hotel bagi para wisatawan yang akan berlibur ke Bali atau tempat destinasi lainnya. Selain itu, pada penelitian selanjutnya, sampel juga bisa diperluas ke wisatawan Australia atau Uni Eropa yang merupakan kelompok wisatawan mancanegara kedua dan ketiga yang paling banyak mengunjungi Bali, setelah wisatawan Cina.

\section{DAFTAR REFERENSI}

Badan Pusat Statistik Provinsi Bali. (2018, June 3). Number of domestic visitor to Bali by month, 2004-2017. Badan Pusat Statistik Provinsi Bali. Retrieved September 19, 2018, from https://bali. bps.go.id/statictable/2018/02/09/29/kunjunganwisatawan-domestik-ke-bali-per-bulan-20042017.html

Bank Indonesia. (2018, August 28). Penguatan sinergi kebijakan untuk mempercepat pengembangan sektor pariwisata sebagai sumber devisa negara. Bank Indonesia. Retrieved September 20, 2018, from https://www.bi.go.id/id/ruang-media/infoterbaru/Pages/Penguatan-Sinergi-Kebijakanuntuk-Mempercepat-Pengembangan-SektorPariwisata.aspx

Dolnicar, S., \& Otter, T. (2003). Which hotel attributes matter? A review of previous and a framework for future research. Proceedings of the 9th Annual Conference of the Asia Pacific Tourism Association (APTA), 1, 176-188.

Gilbert, D., \& Tsao, J. (2000). Exploring Chinese cultural influences and hospitality marketing relationships. International Journal of Contemporary Hospitality Management, 12(1), 45-53.

Irawan, M. H. (2014). Analisa preferensi wisatawan domestik asal Surabaya dalam pemilihan ako- 
modasi di Bali. (TA No. 35010187/MAN/2014). Undergraduate Thesis, Universitas Kristen Petra, Surabaya.

Jones, M. A., Mothersbaugh, D. L., \& Beatty, S. E. (2000). Switching barriers and repurchase intentions in services. Journal of Retailing,76(2), 259274.

Kementrian Pariwisata. (2018). Jumlah kunjungan wisatawan mancanegara menurut pintu masuk dan kebangsaan. Kementrian Pariwisata. Retrieved September 12, 2018, from http://www. kemenpar.go.id/userfiles/12_Lapbul Des 2017 (Angka Revisi).pdf

Lewis, R. C. (1983). Getting the most from marketing research. The Cornell Hotel and Restaurant Administration Quarterly,24(3), 81-85.

Li, X., Lai, C., Harrill, R., Kline, S., \& Wang, L. (2011). When east meets west: An exploratory study on Chinese outbound tourists' travel expectations. Tourism Management, 32(4), 741-749.

Musanef (1996). Manajemen usaha pariwisata di Indonesia. Jakarta: PT Gunung Agung.

Petriella, Y. (2018, October 22). Generasi milenial berpotensi sumbang $70 \%$ kunjungan wisata domestic. Bisnis.com. Retrieved Maret 28, 2019 from https://ekonomi.bisnis.com/read/2018 1022/ 12/851764/generasi-milenial-berpotensi-sumbang-70-kunjungan-wisata-domestik

Prodjo, W. A. (2017, November 18). 10 Destinasi "Bali Baru", 4 destinasi jadi prioritas. Kompas Travel. Retrieved September 20, 2018, from https://travel.kompas.com/read/2017/11/18/1227 00027/10-destinasi-bali-baru-4-destinasi-jadiprioritas

Qu, H., \& Li, I. (1997). The characteristics and satisfaction of Mainland Chinese visitors to Hong Kong. Journal of Travel Research,35(4), 37-41.
Rhee, H. T., \& Yang, S. B. (2015). How does hotel attribute importance vary among different travelers? An exploratory case study based on a conjoint analysis. Electronic Markets, 25(3), 211-226.

Sejati, I.K. (2019). Pahami berbagai karakter wisatawan Indonesia. Retrieved Maret 28, 2019 from https://direktori-wisata.com/pahami-bebagaikarakter-wisatawan-indonesia/

Sihite, R. (2000). Tourism industry. Surabaya: SIC.

Soekadijo, R. G. (1996). Anatomi pariwisata: Memahami pariwisata sebagai "Systemic Linkage". Jakarta: PT Gramedia Pustaka Utama.

Suwantoro, G. (2004). Dasar-dasar pariwisata. Yogyakarta: Andi.

TripAdvisor. (2018). Best destinations in the world Travelers' Choice Awards. TripAdvisor. Retrieved September 11, 2018, from https://www. tripadvisor.com/TravelersChoice-Destinations

Tsai, H., Yeung, S., \& Yim, P. H. (2011). Hotel selection criteria used by Mainland Chinese and foreign individual travelers to Hong Kong. International Journal of Hospitality \& Tourism Administration, 12, 252-267.

Yao, H. Q. (2006). Analysis of the consumption behavior of Chinese outbound tourists (中国出 境旅游者消费行为的分析). Group Economy,29, 78-80.

Yustiana, K. (2018, April 04). Pasar wisatawan domestik yang kian menjanjikan dunia perhotelan. Travel News. Retrieved Maret 28, 2019 from https://travel.detik.com/travel-news/d-3953704/ pasar-wisatawan-domestik-yang-kianmenjanjikan-dunia-perhotelan

Zhou, L., Ye, S., Wu, M., \& Pearce, P. L. (2014). Refreshing hotel satisfaction studies by reconfiguring customer review data. International Journal of Hospitality Management, 38, 1-10. 